\title{
Impact of Mono- and Polyculture Systems on Growth Performance, Feed Utilization, and Economic Efficiency of Oreochromis niloticus, Mugil cephalus, and Mugil capito \\ Mehrim, A. I.; M. M. Refaey; F. F. Khalil and Zohour E. M. Shaban \\ Animal Production Department, Faculty of Agriculture, Mansoura University, Mansoura, Egypt.
}

\section{ABSTRACT}

A field study was conducted to assess the effect of mono- and polyculture systems in net Hapas of monosex Nile tilapia (Oreochromis niloticus), striped mullet (Mugil cephalus) and /or thin-lipped mullet (M. capito) at different stocking ratios on growth performance, feed efficiency, chemical composition of the whole body, and economic efficiency parameters of experimental fish for 107 days rearing period. Five experimental treatments were represented as $100 \%$ Nile tilapia $\left(\mathrm{T}_{1}\right.$, monoculture); $75 \%$ Nile tilapia: $25 \%$ striped mullet ( $\mathrm{T}_{2}$, polyculture); $75 \%$ Nile tilapia: $13 \%$ striped mullet: $12 \%$ thin-lipped mullet ( $\mathrm{T}_{3}$, polyculture); $50 \%$ Nile tilapia: $50 \%$ striped mullet $\left(\mathrm{T}_{4}\right.$, polyculture) and $100 \%$ striped mullet $\left(\mathrm{T}_{5}\right.$, monoculture). Fish of $\mathrm{T}_{2}$ showed the highest significant of all growth performance, feed utilization, and economic efficiency parameters followed by the same fish species reared in polyculture system $\left(\mathrm{T}_{4}\right)$ at stocking ratio (50\%: 50\%) compared to other experimental fish-culture systems. Generally, it could be recommended that rearing monosex $O$. niloticus in polyculture system with $M$. cephalus at stocking ratio $75 \%: 25 \%$, respectively $\left(\mathrm{T}_{2}\right)$ is more effective than other aquaculture systems under the experimental conditions of the present study.

Keywords: Nile tilapia, Striped mullet, Polyculture, Growth performance, Economic efficiency.

\section{INTRODUCTION}

In recent years, aquaculture is the main resource of increasing fish production to meet the increasing demand for fish protein, especially after the stability of productivity from capture fisheries (FAO, 2009). Based on FAO statistics, the increase of fish production from aquaculture led to an increase in per capita consumption of fish to $20.3 \mathrm{~kg}$ in 2016 compared to $9 \mathrm{~kg}$ in 1961 (FAO, 2018). The growing of aquaculture in Egypt has gradually increased over the past few years (Suloma and Ogata, 2006). Egypt's national development strategy includes the objectives of increasing the annual per-capita consumption of fish and confirming the accessibility of affordable fish to the consumer by increasing the national production (Suloma and Ogata, 2006). In Egypt, aquaculture has become the main source of fish protein to cope with the country's growing population. Currently, the total fish production in Egypt increased from 724,300 ton in 2000 to $1,762,174$ ton in 2016 (GAFRD, 2016).

The development of aquaculture systems and technology aims to increase productivity and minimizing the environmental impacts of aquaculture to ensure food safety and sustainability (Bakeer et al., 2008). Also, due to limited sources of freshwater in Egypt, the development and increase of the aquaculture production can be achieved through higher fish stocking density, the application of artificial feeding, and especially through the popularly applicable the polyculture system of different fish species (Abdel-Hakim et al., 2012). Earthen ponds are the major fish-farming system in Egypt. Most ponds are supplied by water with irrigation drainage canals and cultured using semi-intensive methods either as monocultures of Nile tilapia or polyculture of tilapia and other fish species such as mullet and carp (GAFRD, 2014). Polyculture is one strategy can considerably enhance fish production yields by optimizing the use of available resources (Landau, 1992 and Ponce-Marbán et al., 2006). Polyculture is also referred to as multi-trophic aquaculture, coculture or simply integrated aquaculture, which consists of adding one or more fish species to the culture system of the main species (Lanza-Espino et al., 1991 and Bunting, 2008). In addition, polyculture can provide benefits impacts related to progressive ecological stability and function (Gooley and Gavine, 2003). Additionally, polyculture is one approach to developing aquaculture. Most of the aquaculture production in Egypt is pond-based using polyculture farming techniques (GAFRD, 2010).

Nile tilapia (Oreochromis niloticus) are usually reared in polyculture systems with different species such as common carp Cyprinus carpio (Papoutsoglou et al., 1992; Karplus et al., 1996 and Abdel-Hakim et al., 2012), striped mullet Mugil cephalus (Abou Zied et al., 2005; AbdelHakim et al., 2006; El-Dahhar et al., 2006 and Tahoun et al., 2013), African catfish (Liti et al., 2002; Ibrahim and El Naggar, 2010 and Shoko et al., 2014), milkfish Chanos chanos (Cruz and Laudencia, 1980), shrimp (Yi et al., 2002; Kotiya Anil et al., 2010 and Hernández-Barraza et al., 2012), and European eel, Anguilla anguilla (Abdel-Hakim et al., 2000 \& 2001). However, the polyculture systems of Nile tilapia, with striped mullet and thin-lipped mullet are rarely studied. Therefore, the present study was designed to assess the effect of mono- and polyculture systems in net Hapas of monosex Nile tilapia (O. niloticus), striped mullet ( $M$. cephalus) and / or thin-lipped mullet (M. capito) at different stocking ratio for 107 days, regarding the growth performance, feed efficiency, chemical composition of the whole body fish, and economic efficiency parameters.

\section{MATERIALS AND METHODS}

The experimental fish:

Six hundred monosex Nile tilapia fingerlings with an average initial body weight $110 \pm 3.55 \mathrm{~g}$ were purchased from the private fish farm, San El-Baharia, Egypt. While, striped mullet and thin-lipped mullet were purchased from a private fish farm of El-hajj Eid Shaban at the same district (San El-baharia, El-hosania, Al-Sharqia governorate, Egypt), with an average initial body weights $66 \pm 1.62 \mathrm{~g}$ and $70 \pm$ $2.49 \mathrm{~g}$, respectively. The experimental fish of the three species were adapted in net Hapas for two weeks.

After the adaptation period, each fish species was weighed and then randomly distributed and stocked at 100 fish in each net Hapas $(3 \mathrm{~m}$ length $\times 2 \mathrm{~m}$ width $\times 1.5 \mathrm{~m}$ depth; total volume $9 \mathrm{~m}^{3}$ ) at different stocking ratios of fish species. Hapas were constructed and implanted in 1 Feddan (Egyptian area unit $=4200 \mathrm{~m}^{2}$ ) earthen pond in a private fish farm (of El-hajj Eid Shaban). This study was designed to 
include five experimental treatments as described in Table 1; each treatment comprised two net Hapas.

Table 1. Details of the experimental treatments

\begin{tabular}{lc}
\hline Treatment & Fish Species \\
\hline $\mathrm{T}_{1}$ & 100 Tilapia \\
$\mathrm{T}_{2}$ & 75 Tilapia +25 Striped mullet \\
$\mathrm{T}_{3}$ & 75 Tilapia +13 Striped mullet +12 Thin- \\
$\mathrm{T}_{4}$ & lipped mullet \\
$\mathrm{T}_{5}$ & 50 Tilapia +50 Striped mullet \\
\hline
\end{tabular}

\section{Feeding system:}

Fish in all treatments were fed the same commercial pelleted diet contains $(30.95 \%$ crude protein and $4.35 \%$ crude fat), which purchased from Zoo Control Industrialization and Trade Factory belonging to the industrial zone 6 of October, Cairo, Egypt. This commercial diet consisted of soybean meal (44\%), yellow corn, wheatgrass grinders, herring fish meal $(72 \%)$, corn gluten $(60 \%)$, lime stone, dicalcium phosphate, a mixture of mineral salts, a mixture of vitamins, fish oil, and soybean oil, according to the manufacturer's formula. The diet was manually offered to experimental fish twice daily at 8.30 a.m. and 15.00 p.m. The percentage of feeding rate was $4-3 \%$ of the biomass of fish species in each Hapa. The feed amount was adjusted biweekly according to the actual biomass in each Hapa.

\section{The experimental parameters:}

\section{Growth performance and feed utilization:}

At the end of experiment, body weight of monosex Nile tilapia, striped mullet and thin-lipped mullet in each Hapa were measured to calculate the growth performance and feed utilization such as total weight gain (TWG, g), average weight gain (ADG, g/fish/day), relative growth rate (RGR, \%), specific growth rate (SGR, \%/day), feed intake (FI, g), feed conversion ratio (FCR), feed efficiency (FE, \%), protein efficiency ratio (PER, \%), protein productive value (PPV, \%) and energy utilization (EU, \%) according to Halver and Hardy (2002). For chemical analysis of the whole fish body, fish samples $(n=3$ / each fish species in each Hapa) were taken from each Hapa and kept frozen ($20^{\circ} \mathrm{C}$ ) until the chemical analysis was done. The chemical analysis of the experimental diet and the whole fish body was carried out according to AOAC (2004).

Economic efficiency:

At the end of the experiment, total production of all fish species in each treatment $(\mathrm{kg})$ was calculated according to the total weight gain costs (as output). For input, the cost (LE) of fingerlings and food consumption costs are input, regardless of any other costs. The total yield of $O$. niloticus was classified according to body weight to two sizes; size 1 ranged from 413.8 to $570 \mathrm{~g}$ (average $=460.3 \mathrm{~g}$ ) and size 2 ranged from 250 to $385 \mathrm{~g}$ (average $=302.6 \mathrm{~g}$ ) in each Hapa.

\section{Statistical analysis:}

The obtained data such as growth performance and chemical composition of the whole fish body in each of Nile tilapia, striped mullet, and thin-lipped mullet, as well as feed utilization and economic efficiency were subjected to one-way analysis of variance (ANOVA) using (SAS, 2006) version 9.1.3. All ratios and percentages were arcsine-transformed earlier to statistical examines. Mean of each treatment were statistically compared for the significance $(\mathrm{P} \leq 0.05)$ using Duncan's multiple range test (Duncan, 1955).

\section{RESULTS}

Growth performance parameters of Nile tilapia:

$O$. niloticus reared in polyculture system with $M$. cephalus at stocking ratio $75 \%: 25 \%\left(\mathrm{~T}_{2}\right)$ achieved the highest significant $(\mathrm{P} \leq 0.05)$ of all tested growth performance parameters followed by the same fish species reared in polyculture system $\left(\mathrm{T}_{4}\right)$ at stocking ratio $(50 \%$ : $50 \%$ ) compared to other mono- $\left(\mathrm{T}_{1}\right)$ and polyculture systems with $M$. cephalus, and $M$. capito at stocking ratio $75 \%, 13 \%$, and $12 \%$, respectively $\left(\mathrm{T}_{3}\right)$ (Table 2 ).

Table 2. Effect of mono- and polyculture systems on growth performance parameters of Nile tilapia

\begin{tabular}{lccccc}
\hline Treatments & FW $(\mathbf{g})$ & TWG $(\mathbf{g})$ & ADG $(\mathbf{g} /$ fish/day) & RGR (\%) & SGR (\%/day) \\
\hline $\mathrm{T}_{1}$ & $371.5^{\mathrm{c}} \pm 9.84$ & $261.5^{\mathrm{c}} \pm 9.84$ & $2.44^{\mathrm{c}} \pm 0.09$ & $237.8^{\mathrm{c}} \pm 8.95$ & $1.14^{\mathrm{c}} \pm 0.03$ \\
$\mathrm{~T}_{2}$ & $486.7^{\mathrm{a}} \pm 18.33$ & $376.7^{\mathrm{a}} \pm 18.33$ & $3.52^{\mathrm{a}} \pm 0.17$ & $342.4^{\mathrm{a}} \pm 16.66$ & $1.39^{\mathrm{a}} \pm 0.03$ \\
$\mathrm{~T}_{3}$ & $359.4^{\mathrm{c}} \pm 6.96$ & $249.3^{\mathrm{c}} \pm 6.96$ & $2.33^{\mathrm{c}} \pm 0.06$ & $226.8^{\mathrm{c}} \pm 6.33$ & $1.11^{\mathrm{c}} \pm 0.02$ \\
$\mathrm{~T}_{4}$ & $431.5^{\mathrm{b}} \pm 17.06$ & $321.5^{\mathrm{b}} \pm 17.06$ & $3.01^{\mathrm{b}} \pm 0.16$ & $292.3^{\mathrm{b}} \pm 15.52$ & $1.28^{\mathrm{b}} \pm 0.04$ \\
\hline
\end{tabular}

a,b,c: Mean in the same column having different small letters are significantly different $(\mathrm{P} \leq \mathbf{0 . 0 5})$. FW: Final body weight; TWG: Total weight gain; ADG: Average weight gain; RGR: Relative growth rate; SGR: Specific growth rate.

\section{Feed utilization parameters of Nile tilapia:}

Table 3 illustrates the feed utilization parameters of Nile tilapia reared in mono- and polyculture systems. $O$. niloticus reared in polyculture system with $M$. cephalus at stocking ratio $\left(75 \%\right.$ : $25 \%$, respectively, $\left.\mathrm{T}_{2}\right)$ reflected significantly $(\mathrm{P} \leq 0.05)$ increased FE $(\%)$, PER, and PPV $(\%)$, as well as it had the better FCR followed by the same fish species reared in polyculture system $\left(\mathrm{T}_{4}\right)$ at stocking ratio (50\%: 50\%) compared to other mono- $\left(\mathrm{T}_{1}\right)$ and polyculture $\left(\mathrm{T}_{3}\right)$ systems. However, O. niloticus reared in polyculture system with $M$. cephalus at stocking ratio (50\%: $\left.50 \%, \mathrm{~T}_{4}\right)$ was responsible for significantly $(P \leq$ 0.05 ) increased FI and EU followed by the same fish species reared in polyculture system $\left(\mathrm{T}_{2}\right)$ at stocking ratio ( $75 \%$ O. niloticus: $25 \%$ M. cephalus) compared to other mono $\left(\mathrm{T}_{1}\right)$-and polyculture $\left(\mathrm{T}_{3}\right)$ systems.

Table 3. Effect of mono- and polyculture systems on feed utilization parameters of Nile tilapia

\begin{tabular}{lcccccc}
\hline Treatments & FI $(\mathbf{g})$ & FCR & FE (\%) & PER & PPV (\%) & EU (\%) \\
\hline $\mathrm{T}_{1}$ & $479.7^{\mathrm{c}} \pm 0.00$ & $1.84^{\mathrm{a}} \pm 0.07$ & $54.52^{\mathrm{b}} \pm 2.05$ & $1.46^{\mathrm{b}} \pm 0.05$ & $20.42^{\mathrm{c}} \pm 0.80$ & $20.34^{\mathrm{b}} \pm 0.74$ \\
$\mathrm{~T}_{2}$ & $520.9^{\mathrm{b}} \pm 0.00$ & $1.39^{\mathrm{b}} \pm 0.07$ & $72.32^{\mathrm{a}} \pm 3.52$ & $1.94^{\mathrm{a}} \pm 0.09$ & $33.64^{\mathrm{a}} \pm 1.61$ & $24.96^{\mathrm{b}} \pm 1.53$ \\
$\mathrm{~T}_{3}$ & $464.4^{\mathrm{a}} \pm 0.00$ & $1.87^{\mathrm{a}} \pm 0.05$ & $53.70^{\mathrm{b}} \pm 1.50$ & $1.44^{\mathrm{b}} \pm 0.04$ & $25.03^{\mathrm{b}} \pm 0.68$ & $32.33^{\mathrm{a}} \pm 0.76$ \\
$\mathrm{~T}_{4}$ & $541.5^{\mathrm{a}} \pm 0.00$ & $1.70^{\mathrm{a}} \pm 0.09$ & $59.38^{\mathrm{b}} \pm 3.15$ & $1.59^{\mathrm{b}} \pm 0.08$ & $30.44^{\mathrm{a}} \pm 1.55$ & $35.53^{\mathrm{a}} \pm 1.61$ \\
\hline $\mathbf{a}, \mathbf{b}, \mathbf{c}, \mathbf{d}$ : Mean in the same column having different small letters are significantly different $(\mathbf{P} \leq \mathbf{0 . 0 5})$. FI: feed intake; FCR: feed conversion
\end{tabular}
ratio; FE: feed efficiency; PER: protein efficiency ratio; PPV: protein productive value; EU: energy utilization. 
Chemical composition parameters of Nile tilapia:

The highest significant $(\mathrm{P} \leq 0.05)$ fat $(\%)$ and energy content $(\mathrm{KJ} / 100 \mathrm{~g} \mathrm{DM})$ were detected in O. niloticus reared in polyculture system with $M$. cephalus, and $M$. capito at stocking ratio $75 \%, 13 \%$, and $12 \%$, respectively $\left(\mathrm{T}_{3}\right)$ compared to other treatments (Table 4). Where, the highest significant $(\mathrm{P} \leq 0.05)$ crude protein $(\%)$ was noticed in $O$. niloticus reared in polyculture system with $M$. cephalus at stocking ratio (75\%: $25 \%$, respectively, $\left.\mathrm{T}_{2}\right)$ compared to other treatments. However, the dry matter content $(\%)$ was significantly $(\mathrm{P} \leq 0.05)$ higher in $O$. niloticus reared in polyculture system with $M$. cephalus at stocking ratio $\left(50 \%: 50 \%\right.$, respectively, $\left.\mathrm{T}_{4}\right)$ compared to other treatments. Meanwhile, ash content was significantly $(\mathrm{P} \leq 0.05)$ increased in $O$. niloticus reared in monoculture system at stocking ratio (100\%) among all treatments.
Growth performance parameters of striped mullet and thin-lipped mullet:

The obtained findings revealed that $M$. cephalus (25\%) reared in polyculture system with $75 \% O$. niloticus $\left(\mathrm{T}_{2}\right)$ achieved the highest significant $(\mathrm{P} \leq 0.05)$ of all tested growth performance parameters followed by $M$. cephalus reared in polyculture system with $O$. niloticus, and $M$. capito $\left(\mathrm{T}_{3}\right)$ at stocking ratio (13\%: $75 \%: 12 \%$, respectively) compared to other polyculture $\left(\mathrm{T}_{4}\right)$ and monoculture $\left(\mathrm{T}_{5}\right)$ systems (Table 5). For thin-lipped mullet reared in polyculture system $\left(\mathrm{T}_{3}\right)$ give average of $\mathrm{FW}=144.5 \mathrm{~g}$, TWG $=74.5 \mathrm{~g}, \mathrm{ADG}=0.69 \mathrm{~g} /$ fish/day, $\mathrm{RGR}=106.1 \%$ and SGR $=0.67 \% /$ day compared with the average of initial weight $(70 \pm 2.49 \mathrm{~g})$.

Table 4. Effect of mono- and polyculture systems on chemical composition parameters of Nile tilapia

\begin{tabular}{lccccc}
\hline \multirow{2}{*}{ Treatments } & $\begin{array}{c}\text { DM } \\
\text { (\%) }\end{array}$ & Ash (\%) & Fat (\%) & Protein (\%) & EC (KJ/100g) \\
\cline { 2 - 6 } & $25.33^{\mathrm{d}} \pm 0.25$ & $17.89^{\mathrm{a}} \pm 0.33$ & $24.63^{\mathrm{d}} \pm 0.01$ & $57.48^{\mathrm{b}} \pm 0.33$ & $2330^{\mathrm{d}} \pm 1.93$ \\
$\mathrm{~T}_{1}$ & $28.59^{\mathrm{c}} \pm 0.21$ & $12.78^{\mathrm{b}} \pm 0.26$ & $27.63^{\mathrm{c}} \pm 0.01$ & $59.59^{\mathrm{a}} \pm 0.26$ & $2498^{\mathrm{c}} \pm 1.42$ \\
$\mathrm{~T}_{2}$ & $31.75^{\mathrm{b}} \pm 0.05$ & $12.25^{\mathrm{b}} \pm 0.61$ & $34.37^{\mathrm{a}} \pm 0.18$ & $53.38^{\mathrm{b}} \pm 0.79$ & $2618^{\mathrm{a}} \pm 2.71$ \\
$\mathrm{~T}_{3}$ & $32.59^{\mathrm{a}} \pm 0.14$ & $12.12^{\mathrm{b}} \pm 0.07$ & $31.69^{\mathrm{b}} \pm 0.14$ & $56.19^{\mathrm{c}} \pm 0.12$ & $2578^{\mathrm{b}} \pm 0.80$ \\
$\mathrm{~T}_{4}$ & $\mathbf{a}, \mathbf{b}, \mathbf{c}, \mathbf{d}$ : Mean in the same column having different small letters are significantly different (P $\leq \mathbf{0 . 0 5})$. DM: Dry matter, and EC: Energy content.
\end{tabular}

Table 5. Effect of mono- and polyculture systems on growth performance parameters of striped mullet

\begin{tabular}{lccccc}
\hline Treatments & FW (g) & TWG (g) & ADG (g/fish/day) & RGR (\%) & SGR (\%/day) \\
\hline $\mathrm{T}_{2}$ & $338.7^{\mathrm{a}} \pm 93.68$ & $272.8^{\mathrm{a}} \pm 33.68$ & $2.55^{\mathrm{a}} \pm 0.88$ & $413.3^{\mathrm{a}} \pm 41.97$ & $1.41^{\mathrm{a}} \pm 0.28$ \\
$\mathrm{~T}_{3}$ & $234.6^{\mathrm{b}} \pm 32.97$ & $168.6^{\mathrm{b}} \pm 32.97$ & $1.58^{\mathrm{b}} \pm 0.31$ & $255.4^{\mathrm{b}} \pm 49.94$ & $1.16^{\mathrm{b}} \pm 0.14$ \\
$\mathrm{~T}_{4}$ & $180.8^{\mathrm{c}} \pm 11.11$ & $114.8^{\mathrm{c}} \pm 11.11$ & $1.07^{\mathrm{c}} \pm 0.10$ & $173.9^{\mathrm{c}} \pm 16.80$ & $0.94^{\mathrm{c}} \pm 0.06$ \\
$\mathrm{~T}_{5}$ & $163.5^{\mathrm{c}} \pm 13.83$ & $97.53^{\mathrm{c}} \pm 13.84$ & $0.91^{\mathrm{c}} \pm 0.13$ & $147.7^{\mathrm{c}} \pm 20.99$ & $0.84^{\mathrm{c}} \pm 0.08$ \\
\hline
\end{tabular}

a, b, c: Mean in the same column having different small letters are significantly different $(\mathrm{P} \leq 0.05)$. FW: Final body weight;

TWG: Total weight gain; ADG: Average weight gain; RGR: Relative growth rate; SGR: Specific growth rate.

Chemical composition parameters of striped mullet and thin-lipped mullet:

M. cephalus reared in monoculture system $\left(\mathrm{T}_{5}\right)$ achieved significantly $(\mathrm{P} \leq 0.05)$ the highest content of dry matter (\%), crude protein (\%), and energy content (KJ / $100 \mathrm{~g} \mathrm{DM})$ among all experimental polyculture systems $\left(T_{2}, T_{3}\right.$, and $T_{4}$, Table 6). However, fat and ash contents significantly $(\mathrm{P} \leq 0.05)$ increased in $\mathrm{T}_{2}$ and $\mathrm{T}_{4}$, respectively compared to other treatments. With regard, the chemical composition of the whole thin-lipped mullet body reared in polyculture system $\left(\mathrm{T}_{3}\right)$ results appeared $33.11 \%$ DM, $12.44 \%$ ash, $35.69 \%$ fat, $51.87 \%$ crude protein, and 2634 $\mathrm{KJ} / 100 \mathrm{~g}$ EC at the end of the experiment.

Table 6. Effect of mono- and polyculture systems on chemical composition parameters of striped mullet

\begin{tabular}{lccccc}
\hline \multirow{2}{*}{ Treatments } & $\begin{array}{c}\text { DM } \\
\text { (\%) }\end{array}$ & \multicolumn{4}{c}{ On dry matter basis } \\
\cline { 2 - 6 } & $31.45^{\mathrm{b}} \pm 0.16$ & Ash (\%) & Fat (\%) & Protein (\%) & EC (KJ/100g) \\
\hline $\mathrm{T}_{2}$ & $31.51^{\mathrm{b}} \pm 0.03$ & $14.27^{\mathrm{b}} \pm 0.09$ & $33.04^{\mathrm{a}} \pm 0.00$ & $52.39^{\mathrm{d}} \pm 0.10$ & $2542^{\mathrm{b}} \pm 0.52$ \\
$\mathrm{~T}_{3}$ & $29.49^{\mathrm{c}} \pm 0.24$ & $15.26^{\mathrm{a}} \pm 0.11$ & $31.07^{\mathrm{c}} \pm 0.19$ & $54.66^{\mathrm{b}} \pm 0.20$ & $2518^{\mathrm{c}} \pm 2.94$ \\
$\mathrm{~T}_{4}$ & $32.88^{\mathrm{a}} \pm 0.13$ & $11.66^{\mathrm{c}} \pm 0.12$ & $31.28^{\mathrm{c}} \pm 0.03$ & $53.46^{\mathrm{c}} \pm 0.13$ & $2498^{\mathrm{c}} \pm 0.59$ \\
$\mathrm{~T}_{5}$ & & $32.47^{\mathrm{b}} \pm 0.09$ & $55.87^{\mathrm{a}} \pm 0.21$ & $2602^{\mathrm{a}} \pm 0.35$ \\
\hline
\end{tabular}

a, b, c, d: Mean in the same column having different small letters are significantly different $(\mathrm{P} \leq 0.05)$. DM: Dry matter, and EC: Energy content.

\section{Graded size parameters of Nile tilapia:}

The graded size No. 1 basis on fish weight (\%) of $O$. niloticus reared in polyculture system with $M$. cephalus, at stocking ratio $75 \%$, and $25 \%$, respectively $\left(\mathrm{T}_{2}\right)$ increased significantly $(\mathrm{P} \leq 0.05)$ compared to those reared in mono and polyculture systems (Table 7). Meanwhile, $O$. niloticus reared in polyculture system with $M$. cephalus, and $M$. capito at stocking ratio $75 \%$, $13 \%$, and $12 \%$, respectively $\left(\mathrm{T}_{3}\right)$ achieved significantly $(\mathrm{P} \leq 0.05)$ the highest size No.2 based on fish weight (\%) compared to those reared in polyculture $\left(\mathrm{T}_{2}\right)$ and monoculture $\left(\mathrm{T}_{1}\right)$ systems, and with insignificant $(\mathrm{P} \geq$ 0.05 ) difference in case of $O$. niloticus reared in polyculture system $\left(\mathrm{T}_{4}\right)$.
Table 7. Effect of mono- and polyculture systems on graded size parameters of Nile tilapia

\begin{tabular}{lcccc}
\hline \multirow{2}{*}{ Parameters } & \multicolumn{5}{c}{ On fish weight basis (\%) } \\
\cline { 2 - 5 } & $\mathbf{T}_{\mathbf{1}}$ & $\mathbf{T}_{\mathbf{2}}$ & $\mathbf{T}_{\mathbf{3}}$ & $\mathbf{T}_{\mathbf{4}}$ \\
\hline \multirow{2}{*}{ Size No.1 } & $85.29^{\mathrm{a}}$ & $85.49^{\mathrm{a}}$ & $73.77^{\mathrm{b}}$ & $81.93^{\mathrm{ab}}$ \\
\multirow{2}{*}{ Size No. $2^{* *}$} & \pm 0.79 & \pm 2.14 & \pm 3.87 & \pm 3.46 \\
& $14.71^{\mathrm{b}}$ & $14.51^{\mathrm{b}}$ & $26.23^{\mathrm{a}}$ & $18.07^{\mathrm{ab}}$ \\
& \pm 0.79 & \pm 2.14 & \pm 3.87 & \pm 3.46 \\
\hline
\end{tabular}

a, b: Mean in the same row having different small letters are significantly different $(\mathrm{P} \leq \mathbf{0 . 0 5})$.

* Size No.1: fish weight ranged $413.8-570 \mathrm{~g}($ average $=460.3 \mathrm{~g})$

$* *$ Size No. 2: fish weight ranged $250-385 \mathrm{~g}($ average $=302.6 \mathrm{~g})$

Economic efficiency parameters:

Fish (O. niloticus and M. cephalus) reared in polyculture system at stocking ratio $75 \%$, and $25 \%$, 
respectively $\left(T_{2}\right)$ had significantly $(P \leq 0.05)$ increased total outputs, net return, and economic efficiency parameters among all experimental aquaculture systems (Table 8). Meanwhile, M. cephalus reared in monoculture system $\left(\mathrm{T}_{5}\right)$ significantly $(\mathrm{P} \leq 0.05)$ achieved the highest total costs and the negatively lowest total outputs, net return, and economic efficiency parameters among all the experimental polyculture $\left(\mathrm{T}_{2}, \mathrm{~T}_{3}, \mathrm{~T}_{4}\right)$ systems or even monoculture $\left(\mathrm{T}_{1}\right)$ system of $O$. niloticus.

Table 8. Effect of mono- and polyculture systems of experimental fish on economic efficiency parameters

\begin{tabular}{lcccc}
\hline Treatments & Total costs $^{1}$ & Total outputs $^{2}$ & Net return $^{3}$ & Economic efficiency $^{{ }^{4}}$ \\
\hline $\mathrm{T}_{1}$ & $322.6^{\mathrm{d}} \pm 0.00$ & $590.8^{\mathrm{b}} \pm 12.5$ & $268.2^{\mathrm{b}} \pm 12.5$ & $83.2^{\mathrm{b}} \pm 3.88$ \\
$\mathrm{~T}_{2}$ & $356.0^{\mathrm{c}} \pm 0.00$ & $665.1^{\mathrm{a}} \pm 20.6$ & $309.0^{\mathrm{a}} \pm 20.5$ & $86.8^{\mathrm{a}} \pm 5.77$ \\
$\mathrm{~T}_{3}$ & $311.9^{\mathrm{e}} \pm 0.00$ & $481.8^{\mathrm{c}} \pm 18.4$ & $169.9^{\mathrm{c}} \pm 18.4$ & $54.5^{\mathrm{c}} \pm 5.91$ \\
$\mathrm{~T}_{4}$ & $369.3^{\mathrm{b}} \pm 0.00$ & $377.7^{\mathrm{d}} \pm 30.6$ & $30.6^{\mathrm{d}} \pm 0.60$ & $8.3^{\mathrm{d}} \pm 1.28$ \\
$\mathrm{~T}_{5}$ & $380.4^{\mathrm{a}} \pm 0.00$ & $309.1^{\mathrm{d}} \pm 0.0$ & $-71.3^{\mathrm{e}} \pm 0.04$ & $-18.7^{\mathrm{e}} \pm 0.00$ \\
\hline
\end{tabular}

a, b, c, d, e: Mean in the same column having different small letters are significantly different $(P \leq 0.05)$.

1 - Total costs per treatment $(\mathrm{LE})=$ Total cost of feeds per treatment ${ }^{*}+$ Total cost of fingerlings per treatment ${ }^{\text {*n }}$

${ }^{*}$ Total cost of feeds per treatment $(\mathrm{LE})=$ feed costs per one $\mathrm{kg}$ diet $\times$ feed intake $(\mathrm{Kg})$

${ }^{* * *}$ Total cost of fingerlings per treatment $(\mathrm{LE})=$ the cost of fingerlings $/$ each species per treatment $\times$ number fish species in each treatment

2- Total outputs per treatments $(\mathrm{LE} / \mathrm{Kg})=$ fish price $\times$ total fish production

3- Total net return per treatments $(\mathrm{LE})=$ total output - total costs

4- Economic efficiency per treatment $(\%)=($ net return $/$ total costs $) \times 100$

\section{DISCUSSION}

Growth is the process of accumulation of flesh as a result of protein synthesis. Knowledge of fish growth is of energetic importance for obtaining the high yield of fish. The rate of growth differs from species to species and sometimes it differs even within the species also, as well as affected by many factors such as seasonality, fish species, availability of food and oxygen, stocking density, aquaculture system, and age (Dutta, 1994 and Viadero, 2005). In the present study, $O$. niloticus reared in polyculture system with $M$. cephalus at stocking rate $75 \%$ : $25 \%$, respectively $\left(\mathrm{T}_{2}\right)$ achieved the highest significant of all growth performance parameters compared to other mono and poly culture systems. Improving growth performance may be related to mixed cultures between fish species which can show symbiotic effects and food supply for others. Natural feeds of all layers of a water body are properly utilized in polyculture system. Inversely, in monoculture system those feeds are not utilized (Ali et al., 2017). Tahoun et al. (2013) indicated that tilapia-mullet polyculture lead to improving water quality and increasing growth performance, which reflected enhancing the efficiency of natural food resources and system sustainability. The present obtained results are in accordance with the findings of Afifi et al. (1996); Abdel Hakim et al. (2000, 2001 and 2012); El-Dahhar et al. (2006) and El-Sagheer et al. (2008).

One possibility to explain the increased growth of fish in polyculture is based on the nutritional values contained in the food. Typical tilapia assimilation efficiency is $70 \%$ for protein and $51 \%$ for total energy (Bowen, 1982). Therefore, $30 \%$ of the protein and $49 \%$ of the energy would be available to mullet from tilapia feces. Additionally, the higher tilapia density or the higher feeding rate provides more protein and energy available for tilapia and mullet in the polyculture system. The uneaten feed and fecal matter from the tilapia result in better growth of mullet. With uneaten feed, some feed particles always reach the bottom where it becomes available to mullet. More importantly, the fecal matter from the tilapia contributes to the detrital rain that supports the mullet (Yi et al., 2002). Consequently, the species farmed together in one pond as in polyculture technique, tolerate each other's presence, and each species also improves the growth and feed efficiency of the other species (Papoutsoglou et al., 1992).

Among the three tested species, Nile tilapia attained the highest ADG and SGR in comparison with striped mullet and thin-lipped grey mullet; there were no significant differences in growth of thin-lipped grey mullet or striped mullet stocked at different densities. This may be attributable to the fact that Nile tilapia grows faster than mullet. In a 150-d Nile tilapia-striped mullet polyculture trial, Nile tilapia exhibited SGRs of 1.76-1.98\% per day, whereas the SGRs for striped mullet were $1.03-1.31 \%$ per day (Abou Zeid et al., 2005). Moreover, Milstein (1995) found that Nile tilapia demonstrated superior production and higher ADG in a polyculture system when Nile tilapia constituted the majority of cultured organisms in the pond and were farmed with shrimp and mullet. Moreover, Khalil et al. (2011) confirmed the superiority of Nile tilapia $(O$. niloticus) compared with other tilapia species (Sarotherodon galilaeus and Tilapia zillii) reared in polyculture system, regarding to growth performance parameters in all experimental cage's sites.

In the present study, $O$. niloticus reared in polyculture system with $M$. cephalus (at stocking ratio $75 \%: 25 \%$, respectively, $T_{2}$ ) caused significantly increases of feed utilization parameters, and it had the better feed conversion ratio followed by the same fish species reared in polyculture system $\left(\mathrm{T}_{4}\right)$ at stocking ratio $(50 \%: 50 \%)$ compared to other mono- $\left(\mathrm{T}_{1}\right)$ and polyculture $\left(\mathrm{T}_{3}\right)$ systems. This superiority of $O$. niloticus in feed utilization parameters due to the polyculture system with $M$. cephalus at different stocking ratio ( $75 \%: 25 \%$, respectively, $\mathrm{T}_{2}$; or $50 \%$ : $50 \% \mathrm{~T}_{4}$ ), as well as it's potentially related with the highest growth performance parameters among other experimental aquaculture systems. In addition, this performance may be associated with positive trophic feeding interactions between the two fish species (Orina et al., 2018). As in the current findings regarding the positive effects of polyculture system of $O$. niloticus with $M$. cephalus on feed utilization parameters were also reported by Abou Zeid et al. (2005); Eid (2006) and Tahoun et al. (2013). In this respect, Abdel-Tawwab et al. (2005) attributed the positive effect of polyculture to the trophic divergence between species, where the favorite foods of 
mullet are diatoms, while Nile tilapia consumes mostly green algae and cyanobacteria. Furthermore, mullet excrete a significant amount of nutrients that promote the growth of phytoplankton, which as stated above is a primary food source for filter-feeding Nile tilapia (Brusle, 1981; AbdelTawwab et al., 2005 and Kang and Xian, 2008). This synergy in the tilapia-mullet polyculture system leads to an optimized use of the aquatic food web, a reduction in interspecific and intraspecific competition for food, and improvements in feed efficiency.

Generally, the present findings of O. niloticus chemical composition were took unclear trends between all treatments, which may be due to different fish rearing systems, feeding habits, and stocking ratio, which affected the biochemical contents in the body. Where, the polyculture of $O$. niloticus- $M$. cephalus at different stocking rate had significantly increased dry matter, crude protein, fat, and energy contents of $O$. niloticus compared to those reared in monoculture system. These positive effects may possibly relate with the highest growth performance and feed utilization of $O$. niloticus reared in the polyculture system with $M$. cephalus than monoculture system of $O$. niloticus. In agreement with the obtained findings herein, Khalil et al. (2008) concluded that the polyculture system of red tilapia and striped mullet reflected that higher mean of all growth performance parameters and body composition than fish reared under monoculture condition. In addition, the best stocking ratio between two species was 3 red tilapia: 1 striped mullet as gross production. Where, the polyculture is the only possible way of simultaneously producing more than one fish species from the same rearing space (Papoutsoglou et al., 2001). The principle of polyculture is based on the fact that cultured fish species feed different levels of food chain and environment (Milstein et al., 2002). The productivity of the aquatic system is thus increased by more efficiently utilizing ecological resources within the environment. Stocking two or more complimentary fish species can increase the maximum standing crop of a pond by allowing a wide range of available food items and the pond volume to be utilized (Hassan, 2011).

These conflicting results may be related with different factors such as fish feeding habits, fish stocking ratio, and aquaculture systems. Where, the fish polyculture system as practiced in aquaculture via stocking of fish species of different food habits proved to be an important management tool in utilizing efficiently the natural food resources in fish pond. Synergistic interactions among fish species are manifested by higher growth and yield in polyculture than in monoculture (Karplus et al., 1996). The bases for these interactions are the increase of available food resources and the improvement of environmental conditions (Milstein, 1992). In this regard, Hepher (1988) stated that natural food organisms contain low energy, while protein is in excess; therefore, fish consuming only natural food have minimal fat and maximum protein accumulation in their body. These results are also in agreement with findings reported by Weatherley and Gill (1987); Jobling (1994) and Shearer (1994). In addition, Hassan (2011) stated that the chemical composition showed that tilapia and mullet fed zooplankton and reared in polyculture system had significantly higher contents of protein than other fish species fed with artificial feed. These results may be due to the high protein content in zooplankton than artificial feed diets.

Aquaculture plays an important role in the economy (Soliman and Yacout, 2015); where, the polyculture fish farms are well established systems that proved both productive and economic efficiency (Ibrahem et al., 2011). In the present study, fish (O. niloticus and $M$. cephalus) reared in polyculture systems at different stocking ratio, especially $75 \%$ and $25 \%$, respectively $\left(\mathrm{T}_{2}\right)$ achieved the highest total outputs, net return, and economic efficiency parameters than those reared in monoculture system from each species $\left(T_{1}\right.$ and $T_{5}$, respectively). These positive findings in economic efficiency parameters may be strongly relevant with the highest growth performance of both fish species, as well as the highest feed utilization, and graded size of $O$. niloticus reared in polyculture systems than those reared in monoculture system. In this regard, the high biomass production is attributable mainly to high-quality rearing conditions throughout the trial, such as feed and water quality provided by the daily water exchange and the weekly application of fertilizers. Furthermore, owing to the positive influence of striped mullet and thin-lipped grey mullet on water quality, the yield of Nile tilapia and the overall conversion rate of input nutrients were high in the polyculture ponds, consistent with other studies that have reported improvements in Nile tilapia and striped mullet production with economically value in polyculture systems (Milstein, 1995; Eid and ElGamal, 1996; El-Sagheer, 2001 and Abdel-Tawwab et al., 2005). Similarly, Scorvo-Filho et al. (1995) found that the total biomass yield of striped mullet grown in a polyculture system with common carp was greater than that of striped mullet reared in a monoculture system. Also, Dankwa et al. (2004) reported that the economic efficiency and net return showed that the total income from polyculture was higher than those from the monoculture system. Furthermore, the economic and budget analyses revealed that tilapia-mullet polyculture is a feasible technique and can be ecologicalfriendly as well as economically attractive for tilapia farmers (Tahoun et al., 2013).

Polyculture of fishes plays a vital role for nutritional and economical aspects in the fish production (Ali et al., 2017). Where, the present findings regarding the economic efficiency parameters are in full agreement with those reported by Green and El Nagdy (1995) and AbdelHakim et al. (2000) who studied the polyculture system of tilapia, eel, and mullet. Also, Abdel-Hakim et al. (2006) indicated that feeding of the Nile tilapia in polyculture with mullet and common carp in earthen ponds at feeding level of $2.5 \%$ resulted the best economic efficiency. In contrary, Bakeer (2006) reported that M. cephalus reared in monoculture system with supplementary feeding recorded the highest profitability for the lowest stocking density rate of $1 \mathrm{fish} / \mathrm{m}^{3}$. Where, the differences between their results and that obtained findings in the present study may be due to the differences of culture system, experimental management, fish feeding habits, feeding regime, fish species, age, stocking density, and initial bodyweight of cultured fish. 


\section{CONCLUSION}

Based on the obtained results herein, it could be concluded that rearing $O$. niloticus in polyculture system with $M$. cephalus at stocking ratio $75 \%: 25 \%$, respectively $\left(\mathrm{T}_{2}\right)$ is more effective than other aquaculture systems under the experimental conditions of the present study. Additionally, further studies are required for increased stocking density in polyculture technique with other fish species in pond culture.

\section{REFERENCES}

Abdel-Hakim, N.F.; A.A. Al-Azab; H.Y.H. Allam; A.E. Toulan and M.H.M. El-Wahsh (2012). Studies on fertilization sources with artificial feeds on productivity of earthen ponds stocked with different fish species. Egypt. J. Aquat. Biol. \& Fish., 17 (1): 35-53.

Abdel-Hakim, N.F.; M.N. Bakeer and M.A. Soltan (2000). Growth performance of eel (Anguilla anguilla), Nile tilapia (Oreochromis niloticus) and grey mullet (Mugil cephalus) cultured in cages under two feeding systems. Proc. $3^{\text {rd }}$ All Africa Conf. Anim. Agric. \& $11^{\text {th }}$ Conf. Egyptian Soc. Anim. Prod., Alexandria, Egypt, 6-9 November, 329-335.

Abdel-Hakim, N.F.; M.N. Bakeer and M.A. Soltan (2001). Effect of dietary protein levels on growth performance and pond productivity of Nile tilapia (Oreochromis niloticus), eel (Anguilla anguilla) and grey mullet (Mugil cephalus) reared in polyculture system. Egypt. J. Aquat. Biol. \& Fish., 5 (4): 61-85.

Abdel-Hakim, N.F.; M.S. Lashen; M.N. Bakeer and A.A. Khattaby (2006). Effect of different feeding levels on growth performance and pond productivity of the Nile tilapia (Orechromis niloticus), the grey mullet (Mugil cephalus) and the common carp (Cyprinus carpio) stocked at higher rates. Egypt. J. Aquat. Biol. \& Fish., 10 (4): 149 - 162.

Abdel-Tawwab, M.; A.M. Eid; E. Ali; A.E. Abdelghany and H.I. El-Marakby (2005). The assessment of water quality and primary productivity in earthen fishponds stocked with striped mullet (Mugil cephalus) and subjected to different feeding regimes. Turkish Journal of Fisheries and Aquatic Sciences, 5: 1-10.

Abou Zeid, R.M.; A.M. Abd El-Maksoud and A.A. Ali (2005). Effect of stocking rates of Nile tilapia Oreochromis niloticus L. and Grey Mullet Mugil cephalus L. on their performance in polyculture earthen ponds. Annals of Agricultural Science (Moshtohor), 43: 1057-1066.

Afifi, E.A.; A.F. Hafez; N.F. Abdel-Hakim and M.M. Abdella (1996). Effect of mullet stocking rate on some productive traits in fish. Egypt. J. Agric. Res., 74 (2): 2127-2143.

Ali, M.S.; M.S. Islam; N. Begum; I.N. Suravi; M. Mia and M.A. Kashem (2017). Effect of monoculture and polyculture systems on growth and production of fishes in seasonal water bodies of Haor Villages, Sunamganj District. J. Sci. Res. 9 (3): 307-316.
AOAC, (2004). Association of Official Analytical Chemists of Official Methods of Analysis. AOAC International, Arlington, Virginia, USA.

Bakeer, M.N. (2006). Performance of grey mullet (Mugil cephalus L.) reared in monoculture in the new desert areas. Journal of Arabian Aquaculture Society, 1 (2): 44-56.

Bakeer, M.N.; M.A.A. Mostafa and I.M.A. Samra (2008). Effect of Mugil cephalus size and density at initial stocking on growth performance and fish marketable size at harvest. Journal of the Arabian Aquaculture Society, 3: 16-32.

Bowen, S.H. (1982). Feeding, digestion, and growthqualitative considerations. In: R.S.V. Pullin \& R.H. Lowe-McConnel (eds.). The biology and culture of tilapias. Makati, Phillipines: ICLARM, pp. 141156.

Brusle, J. (1981). Food and feeding in Grey Mullet. P.: 185-217. In: Aquaculture of Grey Mullet, (Oren, O. H. Edi.), Cambridge University Press, Cambridge, UK.

Bunting, S.W. (2008). Horizontally integrated aquaculture development: exploring consensus on constraints and opportunities with a stakeholder Delphi. Aquacult. Int., 16: 153-169.

Cruz, E.M. and I.L. Laudencia (1980). Polyculture of Milkfish (Chanos chanos Furskal), all male Nile tilapia (Oreochromis niloticus), and snakehead (Ophicephalus striatus) in fresh water ponds with supplementary feeding. Aquaculture, 20: 231-237.

Dankwa, H.R.; J. Blay and K. Yankson (2004). Potential for culture of Grey Mullets (Pisces: Mugilidae) in Ghana. Ghana Journal of Science, 44:19-27.

Duncan, D.B. (1955). Multiple ranges and multiple F-tests. Biometrics, 11: 1-42.

Dutta H. (1994). Growth in fishes. Gerontology, 40: 97112.

Eid, A.M. (2006). Effect of stocking density on growth performance and production of grey mullet (Mugil cephalus). Egyptian Journal of Aqua cultural Research, Special issue, The First Scientific Conference on Modern Attitudes in Aquaculture; 84 (1): 51-59.

Eid, A.M. and A.A. El-Gamal (1996). Effects of stocking density on growth performance of Nile tilapia Oreochromis niloticus reared in three different culture systems. Journal of Animal Production 33 (Supplemental Issue): 485-495.

El-Dahhar, A.A.; Z.A. Nagdy; T.N. Amer and M.H. Ahmed (2006). Effect of dietary protein level and stocking ratios of striped mullet (Mugil cephalus) and Nile tilapia (Oreochromis niloticus) in polyculture system in net enclosures on growth performance and feed utilization. J. of the Arabian Aquaculture Society, 1 (2): 1 - 18.

El-Sagheer, F.H.M. (2001). Effect of stocking densities, protein levels and feeding frequencies on growth and production of tilapia mono-sex in earthen ponds. Doctoral dissertation. Alexandria University, Alexandria, Egypt. 
El-Sagheer, F.H.M.; E.H. El-Ebiary and H.A. Mabrouk (2008). Comparison between monoculture and Polyculture of tilapia and mullet reared in floating net cages. J. Agric. Sci. Mansoura Univ., 33: 4863 -4872 .

FAO (Food and Agriculture Organization of the United Nations). (2009). The state of world fisheries and aquaculture (SOFIA). FAO, Rome, Italy.

FAO (Food and Agriculture Organization of the United Nations). (2018). The State of World Fisheries and Aquaculture 2018 - Meeting the sustainable development goals. Rome, Italy. Licence: CC BYNC-SA 3.0 IGO.

GAFRD (General Authority for Fish Resources Development). (2010). The 2009 statistical yearbook. Ministry of Agriculture and Land Reclamation, Cairo, Egypt.

GAFRD (General Authority for Fisheries Resources Development) (2014). Fisheries Statistics Year Book 2012. GAFRD, Ministry of Agriculture and Land Reclamation, Cairo.

GAFRD (General Authority for Fishery Resources Development). (2016). Fish Statistics Yearbook 2014. Ministry of Agriculture and Land Reclamation, Egypt.

Gooley, G. and F. Gavine (2003). Integrated Agriaquaculture systems. A resource handbook for Australian industry development RIRDC Publication No. 03/012. Rur. Industries Res. Development Corporation, Canberra, 189 pp.

Green, B.W. and Z. El Nagdy (1995). Evaluation of Nile tilapia production systems in Egypt. Thirteenth Administrative Report. Pond Dynamics/ Aquaculture. Collaborative Research Support Program, Office of International Research and development, Oregon State University, Corvallis Oregon, USA.1-12.

Halver, J.E. and R.W. Hardy (2002). Fish Nutrition. $3^{\text {rd }}$ edn. Academic Press, Elsevier Science Imprint, California, USA. pp: 824.

Hassan, A.A.R. (2011). Zooplankton as natural live food for three different fish species under concrete ponds with mono-and polyculture conditions. Egyptian J. Aquac., 1 (1): 27- 41.

Hepher, B. (1988). Nutrition of Pond Fishes. Formerly of fish and aquaculture station, Dor, Israel. The Press Syndicate of the University of Cambridge. Cambridge, England.

Hernández-Barraza, C.; J. Loredo; J. Adame; M. Kevin and K.M. Fitzsimmons (2012). Effect of Nile tilapia (Oreochromis niloticus) on the growth performance of Pacific white shrimp (Litopenaeus vannamei) in a sequential polyculture system. Lat. Am. J. Aquat. Res., 40 (4): 936-942.

Ibrahem, M.D.; I.B. Shaheed; H. Abo El-Yazeed and H. Korani (2011). Assessment of the susceptibility of polyculture reared African catfish and Nile tilapia to Edwardsiella tarda. Journal of American Science, 7 (3): 779-786.
Ibrahim, N. and G. El Naggar (2010). Water quality, fish production and economics of Nile tilapia, Oreochromis niloticus and African catfish, Clarias gariepinus monoculture and polycultures. Journal of the World Aquaculture Society, 41: 574-582.

Jobling, M. (1994). Fish bioenergetics. Chapman and Hall: London, England.

Kang, B. and W. Xian (2008). C, N and P regeneration by a detritivorous fish, Liza haematocheila $\mathrm{T}$. and S.: effects of temperature, diet and body size. Aquaculture International, 16: 319-331.

Karplus, I.; A. Milstein; S. Cohen and S. Harpaz (1996). The effect of stocking different ratios of common carp, Cyprinus carpio L., and tilapias in polyculture ponds on production characteristics and profitability. Aqua. Res., 27: 447-453.

Khalil, F.F.M.; F.H. Farrag; A.M. Helal and M.M.A. Refaey (2008). Effect of stocking ratios of hybrid red tilapia and striped mullet under different cultivation systems on growth performance, feed utilization and chemical composition of body. J. Agric. Sci. Mansoura Univ., 33 (12): 8463 8472 .

Khalil F.F.M.; A.I. Mehrim; A.A. El-Shebly and M.E.A. Abdelaal (2011). An assessment study of tilapia polyculture in floating net cages. J. Animal and Poultry Production, Mansoura Univ., 2 (5): $75-92$.

Kotiya Anil, S.; B. Gunalan; K.L. Jetani; G. Kuldeep Trivedi and P. Soundarapandian (2010).

Determine the economic feasibility of the polyculture system (giant tiger shrimp and mullet). African Journal of Basic and Applied Sciences, 2 (3-4):124-127.

Landau, M. (1992). Introduction to Aquaculture. John Wiley and Sons, New York, 440 pp.

Lanza-Espino, G.; R. Lara-Andrade and J. GarcíaCalderón (1991). La acuicultura en palabras. AGT, México, 160 pp.

Liti, D.M.; O.E. Mac'Were and K.L. Veverica (2002). Growth performance and economic benefits of Oreochromis niloticus / Clarias gariepinus polyculture fed on three supplementary feeds in fertilized tropical ponds. In K. McElwee, K. Lewis, M. Nidiffer, \& P. Buitrago (Eds.), Nineteenth Annual Technical Report (pp. 11-16). Corvallis, Oregon: Pond Dynamics/Aquaculture CRSP, Oregon State University.

Milstein, A. (1992). Ecological aspects of fish species interactions in polyculture ponds. Hydrobio., 231: 177-186.

Milstein, A. (1995). Fish-management relationships in Israeli commercial fish farming. Aquacult. Int., 3 (4): 292-314.

Milstein, A.; M.A. Wahab and M.M. Rahman (2002). Environmental effects of common carp Cyprinus carpio (L.) and mrigal Cirrhinus mrigala (Hamilton) as bottom feeders in major Indian carp polycultures. Aquac. Res., 33: 1103-1117. 
Orina, P.S.; H. Charo-Karisa; J.M. Munguti; P. Boera; J. Abwao; D. Kyule; M. Opiyo; H. Marcial; J. Manyala and J.O. Rasowo (2018). A comparative study of Labeo victorianus (Bouelenger, 1901) and Oreochromis niloticus (Linnaeus, 1758) grown in polyculture systems. Lakes \& Reserv., 00:1-7.

Papoutsoglou, S.E.; H. Miliou; N.P. Karakatsouli; M. Tzitzinakis and S. Chadi (2001). Growth and physiological changes in scaled carp and blue tilapia under behavioural stress in mono- and polyculture rearing using a recirculated water system. Aquac. Inter., 9: 509-518.

Papoutsoglou, S.E.; G. Petropoutos and R. Barbieri (1992). Polyculture rearing of Cyprinus carpio (L.) and Oreochromis aureus (St.) using a closed circulated system. Aquaculture, 103: 311-320.

Ponce-Marbán, D., J. Hernández and E. Gasca-Leyva (2006). Simulating the economic viability of Nile tilapia and Australian red claw crayfish polyculture in Yucatan, Mexico. Aquaculture, 261: 151-159.

SAS (2006). SAS procedure user's guide. SAS Institute Inc., Cary, NC, USA.

Scorvo-Filho, J.D; S. Da; L.M. Ayroza; N.P.F. Colherinhas and De. Almeida, Dias, E.R. (1995). Effect of density on the growth of striped mullet (Mugil cephalus) reared in mono and polyculture with common carp (Cyprinus carpio), in Vale de Ribeira region. J. Bol. Inst. Resca. Sao. Paulo, 22 (2): 85-93.

Shearer, K.D. (1994). Factor affecting the proximate composition of cultured fishes with emphasis on salmonids. Aquaculture, 119: 63-88.
Shoko, A.P.; S.M. Limbu; H.D.J. Mrosso and Y.D. Mgaya (2014). A comparison of diurnal dynamics of water quality parameters in Nile tilapia (Oreochromis niloticus, Linnaeus, 1758) monoculture and polyculture with African sharp-tooth catfish (Clarias gariepinus, Burchell, 1822) in earthen ponds. International Aquatic Research, 6 (56): 113.

Soliman N.F. and D.M.M. Yacout (2015). The prospects of analyzing the environmental impacts of Egyptian aquaculture using life cycle assessment. International Journal of Aquaculture, 5 (40): 1-9.

Suloma, A. and H.Y. Ogata (2006). Future of rice-fish culture, desert aquaculture and feed development in Africa: the case of Egypt as the leading country in Africa. JARQ (Japan Agricultural Research Quarterly), 40: 351-360.

Tahoun, A.; A. Suloma; Y. Hammouda; H. Abo-State and E. El-Haroun (2013). The Effect of Stocking Different Ratios of Nile tilapia Oreochromis niloticus, striped mullet Mugil cephalus, and thin lip grey mullet Liza ramada in polyculture ponds on biomass yield, feed efficiency, and production economics, North American Journal of Aquaculture, 75 (4): 548-555.

Viadero, R.C. (2005). Factors Affecting Fish Growth and Production. Water Encyclopedia, 3: 129-133.

Weatherley, A.H. and H.S. Gill (1987). The biology of fish growth. Academic Press, London, England.

Yi, Y.; W. Saelee; P. Naditrom and K. Fitzsimmons (2002). Stocking densities for tilapia- shrimp polyculture in Thailand. Twentieth Annual Technical Report, Pond Dynamics/Aquaculture, Collaborateive Research Support Program, Oregon State University, Corvallis, Oregon, USA.

\footnotetext{
تأثير نظامي الاستزراع الأحادي والمتعدد على آداء النمو، الاستفادة الغذائية والكفاءة الإقتصادية لأسماك البلطي النيلي ،

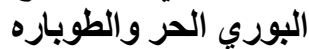

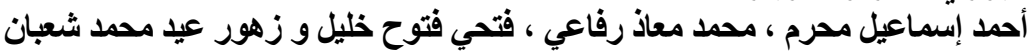

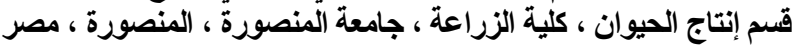

أجريت دراسة حقلية لتقييم نأثير نظامى الاستزراع الآحادى والمتعدد فى تحويطات شبكية (هابات) لأسماك البلطي النيلي، البوري الحر

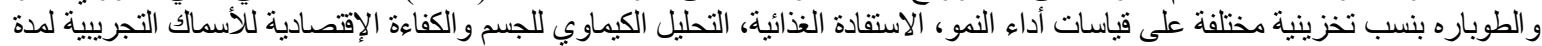

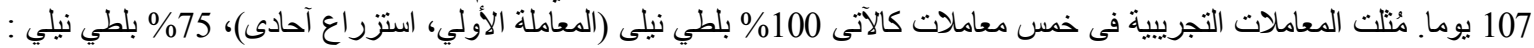

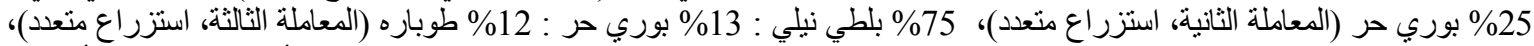

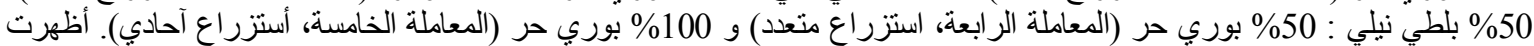

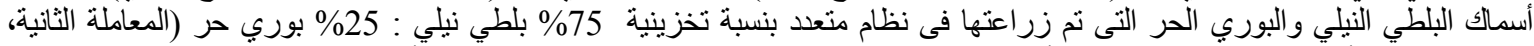

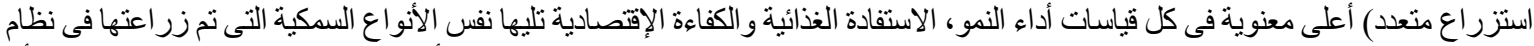

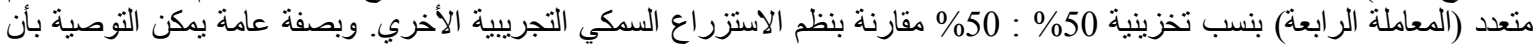

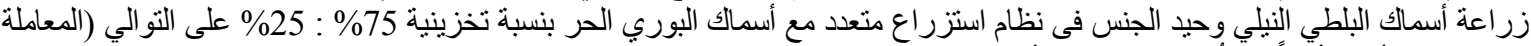
الثانية) هى الأكثر تأثتيراً عن نُظم الاستزر اعل الأخري تحت الظروف التجريبية للار اسة الحالية.
} 